271) D. H. Smith, F. S. Nakayama, F. E. Clark: Soil Sci. Soc. Am. Proc., 24, 145 ('60); 272) D. H. Smith, F. E. Clark: ibid., 24, 111 ('60); 273) D. M. Smith, J. C. Bartlett, L. Levi: Anal. Chem., 32, 568 ('60); 274) E. D. Smith: ibid., 33, 1625 ('61); 275) S. Spencer, H. G. Nadeau: ibid., 33, 1626 ('61); 276) J. C. Sternberg, W. S. Gallaway, D. T. L. Jones: 1961 I. S. A. GC Symposium, I. S. A. Proc., 3, 159 ('61); 277) J. C. Sternberg, R. E. Poulson: J. Chromatog., 3, 406 ('60); 278) G. H. Stewart: Anal. Chem., 32, 1205 ('60): 279) P. H. Stirling, H. Ho: Ind. Eng. Chem., 52, No. 11, 61A ('60); 280) R. Stock: Anal. Chem., 33, 966 ('61).

281) J. Strassburger, G. M. Brauer, M. Tyron, A. F. Forziati: Anal. Chem. , 32, 454 ('60); 282) 菅 孝男: 化 学の領域, 增刊 44, 97 ('61); 283) O. E. Sundberg, C. Maresh: Anal. Chem., 32, 274 ('60); 284) 高山雄二: 工 化, 64，803 ('61)； 285）高山雄二, 武内次夫: “入門ガスクロ マトグラフィー”, 南江堂 ('61)； 286）武内次夫, 石井大道: 工 化, 64, 763 ('61); 287) 武内次夫: 工化, 64, 750 ('61); 288) R. Teranishi, C. C. Nimmo, J, Course: Anal. Chem., 32, 1384 ('60); 289) M. K. Testerman, P. C. McLeod: 1961 I. S. A. GC Symposium, I. S. A. Proc., 3, 125 ('61); 290) W. J. A. VandenHeuvel, E. O. A. Haahti, E. C. Horning: J. Am. Chem. Soc., 83, 1513
('61).

291) W. J. A. VandenHeuvel, C. C. Sweelty, E. C. Horning: J. Am. Chem. Soc., 82, 3481 ('60); 292) A. van der Wiel: Nature, 187, $142\left({ }^{\prime} 60\right)$; 293) M. Vilkas, N. A. Abraham: Bull. Soc. chim. France, 1959, 1651; 294) A. M. Vogel, J. J. Quattrone: Anal. Chem., 32, 1754 ('60)): 295) M. L. Vorbeck, L. R. Matlik, F. A. Lee, C. S. Pederson: ibid., 33, 1512 ('61); 296) A. Wehrli, E. Kovats; J. Chromatog., 3, 313 ('60); 297) A. Weinstein: Anal. Chem., 33, 18 ('61); 298) D. Welti, T. Wilkins: J. Chromatog., 3, 589 ('60); 299) I. M. Whittermore: Office Tech. Services, U. S. Dept. Commerce, Report UCRL-9408 (Sept. 22, 1960); 300) M. Wilkins, J. D. Wilson: J. Appl. Chem., (London), 10, Abstr. i-357, ('60).

301) J. D. Weinfordner, D. Steinbacher, W. E. Lear: Anal. Chem., 33, 515 ('61); 302) W. A. Wiseman: Nature 190, 1187 ('61); 303) 山田 翠: 工化, 64, 1071 ('61)；304）山崎秀郎: 同上, 64, 757 ('61); 305) 山根幹 也: 同上, 64, 759 ('61); 306) A. Zlatkis, H. R. Kaufman: Nature, 184, 2010 ('59); 307) A. Zlatkis, J. F. Oró, A. P. Kimball: Anal. Chem., 32, 162 ('60); 308) W. J. Zubyk, A. Z. Conner: Anal. Chem., 32, 912 ('60).

\title{
11 溶媒抽出
}

\section{石森富太郎・木 村幹*}

溶媒抽出法はますます一般化する傾向にあり，分析化 学の大きな単行本にはかなりのページ数がさかれ(1)2), 単

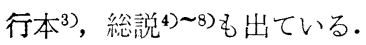

\section{$11 \cdot 1$ 理論的考察}

抽出される化学種の推定と平衡状態についての熱力学 的な取り扱いはきわめて例が多く9) 15), 有機相中におけ る抽出種の状態についても論じられ16 19), 溶媒, 希釈 戍, イオン種を系統的に变えて, 極性20), 誘電率21), 溶

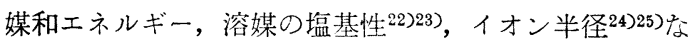
どの観点から考察が行なわれた。速度論的な立場からは 界面圧 ${ }^{26)}$, パラコール ${ }^{27)}$ 導入, 抽出速度と分配にあず かる化学種の生成反応との関係28)などが論じられた.

赤外線吸収などによる抽出反応の機構の解明, 抽出種の 検討29) 35) 乙多い. 今期の一つの特色は Synergism(相 乗作用）の研究が進えだことで, 金属イオンは溶媒和し た錯体の形であるい湿合溶媒和した形で，抽出される 結果抽出率が上昇すると推論されだ6) 39).

\section{$11 \cdot 2$ 試 薬・溶 媒}

アセチルアセトン40), テノイルトリフルオロアセト

* 日本原子力研究所東海研究所（茨城県那珂郡東海村）
ン41), ジチゾン42)，オキシン43)を使った実例は依然とし てきわめて多く, 講座本 ${ }^{44}$ 亿も收録されている.ジェチ ルジチオカルバミン酸 (DEDTC) ${ }^{45)}$, ピリジルアゾナ フトール $(\mathrm{PAN})^{46)}$ も広く研究された. ジチオカルバ ミン酸の誘導体がつくられ，その構造と抽出率の関係が 明らかにされた47)。抽出率は置換基の 鎖の長いほど高 い.

高分子量アルキルアミンの応用の発展は目ざましく49) 置換基とウラン抽出率との関係 ${ }^{49)}$, 多くの金属イオンの 抽出率が明らかにされた50) 53). アミンの級と鉄の塩酸 からの抽出率との関係は $1<2<3$ 級であった ${ }^{54)}$.

オニウム塩の抽出も多数行なわれ，トリブチルアンモ ニウムイオンはひきつゔき応用例に発展を見せ55)，4 級

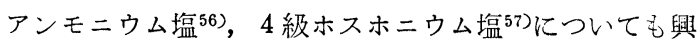
味ある結果が得られ，また多くの元素についてトリエチ ルーベンジル-アンモニウム塩 $-\mathrm{SCN}^{-}-\mathrm{CHCl}_{3}$ 系での挙動 がしらべられた ${ }^{58)}$.

有機リン化合物では TBP の利用が圧倒的に多く， TOPO (トリオクチルホスフィンオキサイド)，DBP， D 2 EHPA（ジブチルリン酸， ジ2-エチルヘキシルリン 酸)なども使われている.トリアルキルリン酸について 置換基の影響がしらべられ，一般に置換基の電気陰性度 
が低いほどウラン，および酸の抽出力が増すことがわか った59)60). またアルキル基と $\mathrm{P}$ と間の酸素の有無につ いては, 一般にない方が抽出力が高い60)61). 多くの元素 について TOPO-鉱酸62), TBP-HCl ${ }^{63)}, \mathrm{TBP}-\mathrm{HNO}^{364)}$, 1\% TBPO-トルェンー $\mathrm{HCl}^{65)}$, D 2 EHPA-トルエン$\mathrm{HCl}^{66)}$ の各系での挙動がしらべられた. TBP について 塩析剤としての $\mathrm{NO}_{3}{ }^{-}$の有効性 67$)$, 抽出された硝酸の 分解の検討 ${ }^{68)}$, 放射線損傷 ${ }^{69)}$, ジおよびモノアルキルリ ン酸の多量体化 ${ }^{70771)}$ の数と溶媒との関係 ${ }^{72)}$, モノアルキ ルリン酸のアルキル基の变化と希土の抽出 ${ }^{73) な と ゙ か ゙ し ら ~}$ ベられた.

メチルイソブチルケトン (MIBK) はヨウ化物74), チ オシアン酸塩などに広範囲に使われており ${ }^{75) 76)}$, 硝酸系 では硝酸塭の影響77)が検討された。

その他ではケタジン ${ }^{79)}$ が新しく, ベンゾヒドロキサミ ン酸79)，アリルメタン系色素80などがひきつづき用いら れ, テトラブチルエチレンジホスホネート30j81), ジオク チル 2 水素-エチレンジホスホネート ${ }^{82), ~}$ ドデシルベン ゼンスルホン酸83)84), ジノニルナフタレンスルホン酸 ${ }^{85)}$ などによる抽出も検討された.

\section{$11 \cdot 3$ 器 具}

大きな発展はなかったようでくりかえし抽出試料を とるための装置86)，ポリエチレンびんを使った操作の簡

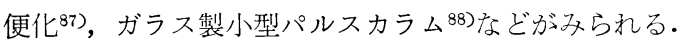

\section{$11 \cdot 4$ 抽出法とその利用}

前回の総説 ${ }^{89}$ に見られる抽出による濃縮 ${ }^{90)}$, 抽出によ る妨害物除去 ${ }^{91)}$, 抽出相の測定, 抽出滴定と抽出指示 薬92)の各項はすべて今回にもあてはまる。追加的な事項 のみ岁述べる，選択性を増すためのしゃへい剂の役割が 詳しく論じられ一覧表にまとめられた ${ }^{93)}$. 抽出した有機 相を適当な充てん剂をつめた柱に通し，吸着させたのち 適当な溶媒でクロマトグラフ的に溶離する力法もかなり 行なわれた ${ }^{94)}$. 向流抽出 ${ }^{95)}$, くり返し抽出 ${ }^{86)}$, 溶融塩か ら TBP 抽出 ${ }^{96)}$, 溶融ジフェニルアミンによる抽出 ${ }^{97) の ~}$ 実例が報告された。同位体希釈法 ${ }^{90)}$, 微量のフッ素イオ ンを Hf の抽出率から求める方法 ${ }^{99)}$, 放射性核種の分配 を測定して TBPO の水と有機相間の分配の計算 ${ }^{100)}$ 行 なわれた。試薬の組み合わせによる発色 ${ }^{101)}$, MIBK あ るいは TBP 中のUの直接ポーラログラフ定量 ${ }^{102)}$, 抽 出有機相に直接発色試薬の添加子行なわれた103). 抽出 分離の系統化も試みられている104) 106).

\section{$11 \cdot 5$ 元素別各論}

Csはジピクリルアミン塩として䣷酸エチルに抽出107).
$\mathrm{Cu}$ はオキシン $-\mathrm{CHCl}_{3}{ }^{108)}$, DEDTC- $\mathrm{Pb}$ 塭 $-\mathrm{CHCl}_{3}{ }^{109)}$,

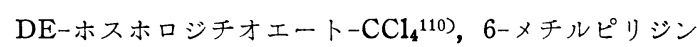
-2-アルドキシム-BuOH ${ }^{111)}$, リン酸塩存在で 1,5-ジフ エニルカルボヒドラジドーベンゼン112), Cit. の存在でネ オクプロイン $-\mathrm{CHCl}_{3}$ または $\mathrm{MIBK}{ }^{113)}$, アンモ二ア性 溶液から

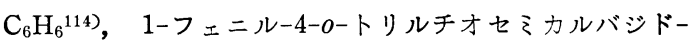
$\mathrm{AmOH}^{115)}$ ，トリフェニル互リン酸一 $\mathrm{CCl}_{4}{ }^{116)}$ などによ り抽出分離が行なるれた。 DEDTC 塩は酶酸イソアミ ルなど117)118)に抽出され，コンプレキソンIII，EDTA，

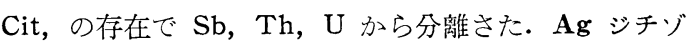
ン抽出 ${ }^{119)}$. サッカリンを使い $\mathrm{TBNH}^{+}$で $\mathrm{CH}_{2} \mathrm{Cl}_{2}$ に 抽出， $\mathrm{Cu}, \mathrm{Pb}$ などから分離された ${ }^{120)} . \mathrm{Au}$ は $\mathrm{HCl}$, $\mathrm{F}^{-}$の存在でテトラフェニルアルソニウクロライドで $\mathrm{CHCl}_{3}$ に抽出 ${ }^{121)}$. $\mathrm{HNO}_{3} \cdot \mathrm{HCl}$ からポリオキシエチレ ングリコールでジクロロエタンに抽出，>200 倍量の $\mathrm{Co}, \mathrm{Fe}, \mathrm{Pd}, \mathrm{Pt}$ などから分離され ${ }^{122)}, \mathrm{HCl} \cdot \mathrm{HNO}_{3}$ から 酢酸エチルに抽出 $\mathrm{Cu}$ から分離された ${ }^{123)}$. $\mathrm{Be}$ は $\mathrm{HCl}$, HF から D2EHPA に ${ }^{124)}$, EDTA の存在でアセチルア セトン125)あるい法ヒドロキシキナルジン126) 錯体として $\mathrm{CHCl}_{3}$ に, また酪酸塩 ${ }^{127)}$ ， ペルフルオロ酪酸塩 ${ }^{128)}$ と して $\mathrm{CHCl}_{3}$, エーテルに, それぞれ抽出され, $\mathrm{Mg}$ な どから分離された. Mg は $\mathrm{tar}$., 4 級アンモニウム塩存 在でオキシン $-\mathrm{CHCl}_{3}$ に抽出, アルカリ土類元素から分 離された ${ }^{129) . ~ C a ~}$ 棌アルカリ性からグリオキサルビス (2-ヒドロキアニル) で $\mathrm{CHCl}_{3}$ に抽出さ礼る130). Zn はオキシン $-\mathrm{CHCl}_{3}{ }^{131)}, \mathrm{MIBK}{ }^{132}$ ) 抽出, 多くの元素 をジエタノール-DTC 塩でしゃへいしジチゾン抽出133) する方法は良好な結果它与え同位体希瀵法を応用して $10^{-9} \mathrm{~g} / \mathrm{ml}$ の定量が可能 ${ }^{134)}$. 鋳鉄などの中の Cd はシ チゾン抽出135). チオ硫酸塩, pH 5.5 で抽出寺れば $\mathrm{Zn}$ は抽出され Cd 㱙残る136). Cd, Zn は DEDTC-䣷酸 エチルで抽出され， $\mathrm{HCl}$ で逆抽出してのち 10\% 以下 の $\mathrm{NH}_{3}$ の存在で $\mathrm{Cd}$ の文を再抽出 ${ }^{137} . \mathrm{Hg}$ もジヂ ン法が多く見られ ${ }^{138) 139), ~}$ 同位体希釈法で $10^{-10} \mathrm{~g} / \mathrm{ml}$ まで定量可能 ${ }^{142)}$. ジフェニルカルバゾンー $\mathrm{C}_{6} \mathrm{H}_{6}{ }^{141)}$,

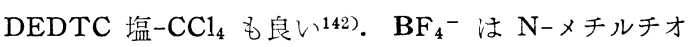
ニンなどと結合して $\mathrm{CH}_{2} \mathrm{Cl}_{2}$ に ${ }^{143)}$ ， クリスタルバイオ レット144)あるいはブリリアントグリーン145) と $\mathrm{C}_{6} \mathrm{H}_{6}$ に， また $\mathrm{Si}$ 中の $\mathrm{B}$ は $\mathrm{Br}_{2}, \mathrm{BuOH}$ 存在でイソプロピルエ ーテルに ${ }^{146)}$ ，それぞれ抽出された．A1 注他金属をしゃ ヘい寸るか147, DEDTC 塩- $\mathrm{CHCl}_{3}$ などの方法であらか じめのぞいて ${ }^{148)}$ ，オキシン- $\mathrm{CHCl}_{3}$ 抽出，ポンタクロー ムブラック $\mathrm{R} \mathrm{AmOH}$ 抽出,ケイ光分析子行なわれた ${ }^{149)}$. Ga は $\mathrm{Ti}$ (III) で妨害金属（T1 など）学残してローダ 
乏ン $\mathrm{B}-\mathrm{C}_{6} \mathrm{H}_{6}$ に抽出される150). $\mathrm{HCl}$-エーテル抽出後, ふりもどし，8-オキシキナルジン- $\mathrm{CHCl}_{3}$ に再抽出する 方法もある151). In は $6 N \mathrm{HBr}$ からイソプロピルエー テル抽出, 逆抽出後 8-メルカプトオキシンでトルエンに 抽出 ${ }^{152)}$. $\mathrm{PAN}$ 錯体- $\mathrm{CHCl}_{3}{ }^{153)}$, ローダミン $6 \mathrm{G}$ 踖体一 $\mathrm{C}_{6} \mathrm{H}_{6}{ }^{154)}$, ジブチルアンモニウム硫化インジウム $-\mathrm{CH}_{2}$. $\mathrm{Cl}_{2}{ }^{155}$ ) に抽出される. 最後の場合は $\mathrm{HNO}_{3}$ つづいて $\mathrm{NH}_{3}$ を加えると硫化物が沈殿. T1 は 2M HBr から イソプロピルエーテルなどに抽出155)156)， クリスタルバ イオレットートルエン157)，チオキシンートルエン152)も用 いられた. 希土類元素は $\mathrm{pH} 5.5$ で TTA-MIBK に 抽出, ただちに炎光分光分析 ${ }^{158)}$, DBP による抽出率の 検討も出た ${ }^{70) 159)}$. ${ }^{90} \mathbf{Y}$ は $16 \mathrm{~N} \mathrm{HNO}_{3}$ から TBP 抽出, 放射能を測定して ${ }^{90} \mathrm{Sr}$ の量を推定 ${ }^{160)}$. Ce は $\mathrm{Ce}(\mathrm{IV})$ として D2EHPA-ヘプタンで抽出し, $10 M \mathrm{HNO}_{3}, 3 \%$ $\mathrm{H}_{2} \mathrm{O}_{2}$ で逆抽出して $\mathrm{U}, \mathrm{Pu}, \mathrm{FP}$ から分離された161). $\mathrm{Ce}(\mathrm{I})$ TTA 錯体を $\mathrm{C}_{6} \mathrm{H}_{6}$ に抽出 ${ }^{162)}$. Pm は D2EHPA を使い段階的に抽出, 逆抽出を行なって精製された163). ウランの中の希土颣は，TOPO ${ }^{164)}$ また注トリオクチ ルアミン165)でウランなどをのぞいてのち比色あるい は TTA 抽出精製定量される. Si はいずれもモリブデ ン酸の存在で, トリイソデシルアミンートルエンに ${ }^{166)}$, MIBK に ${ }^{167) ， ま た は イ ソ-A m O H ~}{ }^{168)}$ に抽出された. $\mathrm{GeCl}_{4}$ は莀 $\mathrm{HCl}$ から $\mathrm{CCl}_{4}$ または $\mathrm{MIBK}$ に抽出 ${ }^{169)}$, フェニルフルオロン錯体は $0.5 N \mathrm{HCl}$ からベンジルア

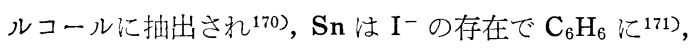
アスコルビン酸, $\mathrm{SCN}^{-}$共存下で酢酸エチルに抽出さ れる172). トリ-2EHPO-シクロヘキサン173)，チオグリ コール- $\mathrm{CHCl}_{3}$ 抽出もある(74). $\mathbf{P b}$ は DEDTC 程と して $\mathrm{CCl}_{4}{ }^{175)}$ または $\mathrm{CHCl}_{3}{ }^{176)}$ に, $\mathrm{KI}, \mathrm{TBNH}^{+}$と存 在で $\mathrm{CH}_{2} \mathrm{Cl}_{2}{ }^{177)}$ に抽出される. ジチゾンによる濃縮 ${ }^{178)}$ も行なわれた。 Ti は $\mathrm{SCN}^{-}$の存在で $6 \mathrm{M} \mathrm{HC1} \mathrm{から}$ TOPO-シクロヘキサンに抽出 ${ }^{179)} . Z \mathbf{r}$ が TBP で良く 抽出されるのは DBP によるところが大きいとされた ${ }^{180)}, \mathrm{DBP}, \mathrm{MBP}$ による抽出 ${ }^{181)}, \mathrm{TBPO}-\mathrm{CCl}_{4}$ で ${ }^{95} \mathrm{Nb}$ からの分離182)が行なわれた. Hf は $\mathrm{SCN}^{-} 3 \mathrm{M}, \mathrm{HCl}$ $1.5 \mathrm{~N},\left(\mathrm{NH}_{4}\right)_{2} \mathrm{SO}_{4} 2.5 \mathrm{M}$ からへキサノン抽出, $\mathrm{Zr}$ か らの分離係数が高い. Th は TOPO- $\mathrm{HNO}_{3}$ で Be か ら ${ }^{184)}$, TBP でX線分析の妨害となる $\mathrm{Bi}, \mathrm{Sr}$ から ${ }^{185)}$,

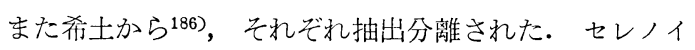
ル-2-アセトンー $\mathrm{CHCl}_{3}$ 抽出187), $\mathrm{LiNO}_{3}$ 存在でメシチ ルオキサイド抽出も行なわれた ${ }^{188)}$ ～P はモリブデ ン酸を加え $\mathrm{MIBK}, \mathrm{BuOH}, \mathrm{BuOAc}$ あるい注 $\mathrm{BuOH}$

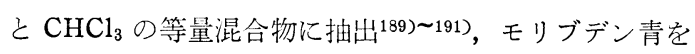
$\mathrm{BuOH}$ に抽出 ${ }^{192)}$, フェロクロム中の $\mathrm{P}$ はFe, Crを $\mathrm{MIBK}$
に抽出除去して比色 ${ }^{193)}, \mathbf{A s}$ は $\mathrm{NH}_{4} \mathrm{I}-\mathrm{HCl}$ または $\mathrm{Cu}$. Cl-HCl から $\mathrm{C}_{6} \mathrm{H}_{6}$ または $\mathrm{CCl}_{4}$ に抽出するか 194)195), DEDTC のヨウ化ヒ素( III)塩を $\mathrm{CCl}_{4}{ }^{196}$ ) 抽出する. $\mathrm{Sb}(\mathrm{V})$ は $8 \mathrm{~N}$ 以上の $\mathrm{HCl}$ でイソ-AmOAc に抽出さ れる197). $7 \mathrm{M} \mathrm{HCl}, 6 M \mathrm{H}_{3} \mathrm{PO}_{4}$ からジイソブチルカル

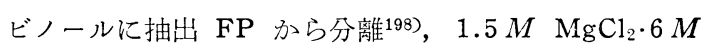
$\mathrm{HCl}$ からイソプロピルエーテルに抽出199), クリスタル バイオレットを用いトルエンに抽出(157), メチルフルオ ロンを用い $\mathrm{pH} 2$ で MIBK などに抽出200)が行なわれ た. Bi は $\mathrm{KI}$ の存在でイソ-AmOAc とイソーAmOH の混合物に抽出 ${ }^{201)}$. $\left(\mathrm{C}_{6} \mathrm{H}_{5}\right)_{4} \mathrm{PBr}$ で $\mathrm{CHCl}_{3}$ 抽出 ${ }^{202)}$, DEDTC 塩として $\mathrm{CCl}_{4}$ などに抽出 ${ }^{203)}$. V(V) は有機 の基を持ったヒドロキシラミンにより $\mathrm{CHCl}_{3}$ に抽出, 多くの元素から分離された204)205). エチルキサントゲン 酸- $\mathrm{CHCl}_{2}$ 抽出でWとの分離が行なわれた ${ }^{206)} . \mathrm{Nb}$ はFの存在で $\mathrm{MIBK}$ に207), $\mathrm{SCN}^{-}$および $\mathrm{TBNH}_{4}{ }^{+}$の存在 でイソ-AmOAcに抽出された ${ }^{55)}$. フラボノール-MIBK を使って ${ }^{95} \mathrm{Zr}$ から ${ }^{95} \mathrm{Nb}$ の分離が行なわれ208)， N-ベ ンゾイルフェニルヒドロキシラミン $-\mathrm{CHCl}_{3}{ }^{209)}$, オキシ ン- $\mathrm{CHCl}_{3}{ }^{210)}$ も使われた。 $\mathrm{Ta}$ は $\mathrm{F}^{-}$を含む $\mathrm{pH} 1.9$ 〜2.3 でメチルバイオレットと反応し, 生成物はトルェ ンに抽出される. $\mathrm{Nb}$ は反応しない211). $\mathrm{Nb}$, Ta の抽 出の諸種の検討も行なわれた ${ }^{212)}$. $\mathbf{P a}$ は $\mathrm{HNO}_{3}$ 塩析剂 存在でジイソプロピルケトン, MIBK, 酶酸アミルなど に抽出され213)，また $\mathrm{HNO}_{3}-(\mathrm{HF})$ の存在でジイソプロ ピルカルビノールにより照射 $\mathrm{Th}$ から分離され ${ }^{233)}, \mathrm{Pa}$ の放射能が検査された ${ }^{214)}$. Se 注もつぱらギ酸, EDTA の存在で $3,3^{\prime}$-ジアミノベンジシンートルエン抽出が行 なわれ, 抽出条件の詳細な検討 ${ }^{215)}$, Te 中の Se の分 析 $^{216)}$, 抽出後直接ケイ光分析の試み ${ }^{217)}$, 地球化学的試 料への応用218)219)が見られる. Te $\mathrm{SCN}^{-}$, チオウレ ア存在で TBP に抽出 ${ }^{220)}, \mathrm{SnCl}_{2}, \mathrm{CN}^{-}, \mathrm{PO}_{4}^{3-}$, $\mathrm{BO}_{3}{ }^{3-}$ などの存在 $\mathrm{pH} 8.6$ で DEDTC-塭として $\mathrm{CCl}_{4}$ に抽出221)，ビスムチオールI 行なわれた. 最後の方法では Se かじめ除去しておくことを推奨しており，ほふの多くの 金属の妨害はない.Po 注 MIBK への抽出が詳細に検 討された223). $6 \mathrm{M} \mathrm{HCl}, 1 \mathrm{M}$ 以下の $\mathrm{HNO}_{3}$ からジイ ソプロピルまたはジイソブチル・カルビノールに抽出さ れ $\mathrm{Bi}$ ターゲットから ${ }^{203} \mathrm{Po}$ の分離に使われた ${ }^{224)}$. $\mathrm{Cr}(\mathbb{I I})$ は $\mathrm{pH} 5.75$ から TTA-ベンゼンに ${ }^{225)}$, 同様 の $\mathrm{pH}$ 域から 2-メチルオキシン $-\mathrm{CHCl}_{3}$ に226)抽出され た. $\mathrm{Cr}(\mathrm{IV})$ は $1 \sim 3 N \mathrm{HCl}$ から MIBK に抽出, 直接 比色 227 あるいは $5 \% \mathrm{KOH}$ でふりもどして定量228)され る.直接比色の際はVはチ才硫酸 $\mathrm{Na}$ で $\mathrm{V}(\mathbb{V})$ にしてお 
く, $\mathrm{Mo}$ の抽出は, $\mathrm{SCN}^{-}, \mathrm{Br}^{-}$存在で $\mathrm{MIBK}$ に $^{2299}$, $\mathrm{SCN}^{-}, \mathrm{SnCl}_{2}$ 存在で, 3,4-ジクロロベンジルトリフェ ニルホスホニウム塩として $\mathrm{CHCl}_{3}{ }^{57)}$ に, $\mathrm{F}^{-}$, モーリン 存在でブタノールに ${ }^{230)}$ それぞれ抽出された. 6,7-ジヒ ドロキシ-2,4-ジフェニルベンゾピリリウムにより鉄鋼 中231)の,オキシン $-\mathrm{CHCl}_{3}{ }^{210)}$ あるいは $\mathrm{HCl}$ から酢酸ブ チル ${ }^{232}$ によりウラン中の, Mo が分離された. またベン ゾインー $\alpha$-オキシムー酰酸エチル233), エチルキサンドゲ

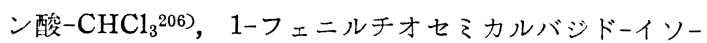

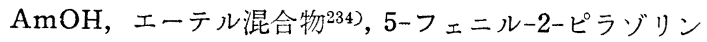
-1-ジチオホルミック酸- $\mathrm{CHCl}_{3}{ }^{235)}$ などにより抽出が行 なわれた、W は $\mathrm{SCN}$ 錯塩を $6 N \mathrm{HCl}$ から $\mathrm{AmOH}$ 抽 出.鉄注イソプロピルエーテルで,Mo はエチルキサント ゲン酸（弱酸性で）それぞれ分離すればよい236)。 $\alpha$-ベ ンゾインオキシムによる抽出の検討が行なわれた237). I を金属错イオンの形にして TBP, MBK, シクロヘキ サノンなどに抽出する試みがなされた ${ }^{105) 238) . ~} \mathrm{CN}^{-}$, CNS- なども同程度に抽出される239)。Cl は同様 $\mathrm{Hg}$ と反応させ，ジフェニルカルバゾンーエタノール溶液を 加えベンゼンに抽出，〜1 ppm Cl- の定量が行なわれ た239). At は $\mathrm{Ce}(\mathrm{IV})$ または $\mathrm{Cl}_{2}$ で酸化，ジイソプ ロピルエーテルに抽出された. $\mathrm{HNO}_{3}, \mathrm{H}_{2} \mathrm{SO}_{4}, \mathrm{HClO}_{4}$ 各 1〜 $M$ について検討され， 4〜 $M$ 抽出が行なわ れることがわかった 240). Mn は酸化したのち，テトラ フェニルアルソニウム・過マンガン酸塩としてニトロベ ンゼンに抽出された ${ }^{241)}$. Te はアルカリ性 $(\mathrm{NaOH}$, $\mathrm{Na}_{2} \mathrm{CO}_{3}$ を含む) 溶液からピリジンに抽出される. 2,4ジメチルピリジン $\mathrm{NO}_{3}$ - ある時も抽出率が高く有用 である ${ }^{242)}$. トルエン-3,4-ジチオールー $\mathrm{CCl}_{4}$ 抽出も行な われた ${ }^{243)}$. Tc が還元剂の存在でジチゾンと $\mathrm{CHCl}_{3}$ に 抽出される塩它つくることがわかった ${ }^{244)}$. Re は $\mathrm{Tc}$ と 同椂にピリジンで抽出される. 抽出率は一般にTcの方 が高い242). $4 N \mathrm{KOH}$ から抽出してWからの分離が行な われた ${ }^{245)}$. $\mathrm{pH}$ 4〜8 でマラカイトグリーンあるいはク リスタルバイオレットとの反応体をトルエンに抽出 ${ }^{246)}$, 還元剤の存在で $\alpha$-フリルジオキシムーシクロヘキサン抽 出 ${ }^{247)}$, テトラフェニルアルソン酸 $-\mathrm{CHCl}_{3}{ }^{248)}$ 抽出も行 なわれたＦe はジベンゾイルメタンー酢酸ブチル249),

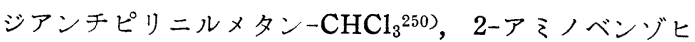
ドロキサミン酸 $\mathrm{Fe}$ (II ) (III)-イソブチルアルコール251), 1-ニトロソ-2-ナフトール酢酸エチル252) あるいはイソペ ンチルアルコール 253), 2-, 1-ナフトール-MIBK ${ }^{252)}$, ジ ピリジン, アセチルアセトン- $\mathrm{CCl}_{4}{ }^{254)}$ ，オキシン-CH. $\mathrm{Cl}_{3}{ }^{147)}$ ，TTA-ベンゼン ${ }^{255)}$ などの諸系が分離対象の相 違とともにいろいろと検討された. SCN 錯体の MIBK
抽出 ${ }^{256)}$, 希 $\mathrm{HCl}$ から $\mathrm{TBP}$ ら抽出257)258)で $\mathrm{Ni}, \mathrm{Co}$, $\mathrm{Cu}$ からの分離, TOPO-シクロヘキサン抽出259)も行な われた. Co: 1-ニトロソ-2-ナフトール錯体をベンゼン 抽出 ${ }^{260) 261)}$, DEDTC 錯体を $\mathrm{pH}$ 4 10 がら ${ }^{262)}$, 微ア ルカリ性から 263) $\mathrm{CCl}_{4}$ 抽出, $\mathrm{CaCl}_{2}$ 存在でイソアミル アルコール抽出264)が行なわれた. Be 中の Co は Be な どをアセチルアセトン $\mathrm{pH} 4$ で抽出除去してのち, SCN 錯体としてアセチルアセトン-ベンゼン抽出 ${ }^{265)}$. Ni 鋼 中の Co は $10.5 N \mathrm{HCl}$ から TBP 抽出 ${ }^{266)}$. この方法 は $\mathrm{Co}, \mathrm{Ni}$ の分離に用いられる257). Ni は $N, N^{\prime}$-ビス (o-アミノベンジリデン) エチレンジアミン, $\mathrm{pH} 9.6$ 以 上でベンゼン抽出267). PAN を用い $\mathrm{pH}$ 4 10 で $\mathrm{MIBK}, \mathrm{CHCl}_{3}, \mathrm{C}_{6} \mathrm{H}_{6}$ などに抽出 ${ }^{268)}$, ジメチルグリオ キシムを使う例は多い269)270). $\mathrm{Ru}: \mathrm{RuO}_{4}$ を $\mathrm{CCl}_{4}$ に抽 出 ${ }^{271}, \mathrm{NaHCO}_{3}$ 存在 $\mathrm{pH} 3.73$ でアセチルアセトンー

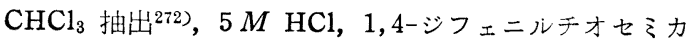
ルバジド- $\mathrm{CHCl}_{3}$ 抽出273)などがある， Ru， Rh, Pd, Ptを連続的に分離しようとする試みが行なわれ，3４ $N \mathrm{HCl}, \mathrm{KSCN}$ で $\mathrm{Rh}$ を, $2 N \mathrm{HCl}, \mathrm{KSCN}$, ピリシ ン存在で $\mathrm{Ru}, \mathrm{pH} 2 \sim 2.5, \mathrm{KSCN}$, ピリジン存在 で $\mathrm{Pt}$ を, $\mathrm{pH} 11 \sim 12, \mathrm{KSCN}$, ピリジン存在で $\mathrm{Pd}$ を，それぞれ MIBK に抽出できた ${ }^{274) ， こ の ほ か ~ P d ~}$ は $\mathrm{pH} 2 \sim 5$ で $\mathrm{PAN}$ 錯体として $\mathrm{CHCl}_{3}{ }^{275}$ ) に, $\mathrm{pH}$ 3〜4 で $\alpha$-フリルジオシムにより $\mathrm{C}_{6} \mathrm{H}_{6}$ に276), $2.8 \mathrm{~N}$ $\mathrm{HNO}_{3}, 6 \mathrm{~N} \mathrm{H}_{2} \mathrm{SO}_{4}$ で 2-ニトロソ-1-ナフトール-4-ス ルホン酸によりイソ-AmOH に277)それぞれ抽出される. ジメチルグリオキシムを使う例もある278)279). Os は $\mathrm{OsO}_{4}$ として $\mathrm{CHCl}_{3}$ に抽出280). Ir は $\mathrm{HCl}$-TBP 系で $\mathrm{Rh}$ から分離 ${ }^{281)}$. U は $\mathrm{pH} 9.5 \sim 10 \mathrm{PAN}-\mathrm{CHCl}_{3}{ }^{282)}$, $\mathrm{pH} 6.2$ ベンゾヒドロキサミン酸- $\mathrm{BuOH}^{283)}$ ，アルセン アゾ-EBK ${ }^{2843285)}, \mathrm{pH} \mathrm{6〜7} \mathrm{ジベンゾイルメタン-Bu・}$ $\left.\mathrm{OAc}^{286)}, \mathrm{HNO}_{3}(1: 20), \mathrm{Al}(\mathrm{NO})_{3}-\mathrm{EtOAc}^{287}\right), \mathrm{Zn}$ ア マルガムクペロン $-\mathrm{CHCl}_{3}{ }^{288)}, \mathrm{pH}$ 8.5〜9 オキシンー $\mathrm{CHCl}_{3}{ }^{287)}$, ドデシルリン酸290), ジアルキルリン酸291)な どの諸系により，しゃへい剤を適当に用いるなどして分 離，分析が行なわれた。有機アミン，リン酸系について は理論試薬の項などを参照されたい。 $\mathrm{Np}$ は $\mathrm{HClO}_{4}-$ TBP 系で U, FP から分離された ${ }^{292}$. M 2 EHPA で $\mathrm{Pu}$ から分離293)，Pu(V) は $\mathrm{U}, \mathrm{Np}$ とともに， テ トラプロピルアンモニウムトリニトラト塩として, MIBK に抽出される ${ }^{294)}$. このほか TBPO による抽出

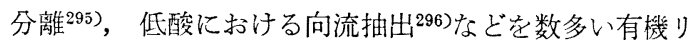
ン酸系抽出の一例としてあげておこう。 U, Puなどの 抽出種の決定は J. Inorg. Nucl. Chem., Radiokhimiya などに多いことを付記する。AmCm を希土 
類元素から, $\mathrm{Am}$ を $\mathrm{Cm}$ から分離するために $0.1 \mathrm{M}$ $\mathrm{HCl}, 12 M \mathrm{LiCl}-20 \%$ トリイソオクチルアミンといっ た条件が選ばれた 297 ). Cm，Cf の Pu からの分離も行 なわれた ${ }^{298}$ 。 FP の系統的分離も試みられている104)。

\section{交 献}

1) H. Irving, R. J. P. Williams: "Treatise on Analytical Chemistry, Part I. Vol. 3, Chapter 31" ('61), (I. M. Kolthoff, P. J. Elving, ed., Interscience Publishers Inc., N. Y.); 2) G. H. Morrison, H. Freiser: "Comprehensive Analytical Chemistry: 1A, Chapter II-7", ('59), (C. L. Wilson, D. W. Wilson, ed., Elsevier Pub. Co., Amsterdam); 3) V. V. Fomin: "Khimiya Ekstraktsionnykh Protsesoy” 166 ('60) (Atomizdat, Moscow); H. Freiser, G. H. Morrison; "Annual Review of Nuclear Science, Vol. 9", 221 ('59), (E. Segrè, L. I. Schiff, coed., Annual Reviews. Inc.); 5) R. M. Diamond, D. G. Tuck: "Progress in Inorganic Chemistry, Vol. 2", 109-192 ('60) (F. A. Cottor ed., Interscience Publishers Inc, N. Y); 6) B. Tremillon; Bull. Soc. chim. France, 1960, 160; 7) G. H. Morrison, H. Freiser: Anal. Chem., 32, $37 \mathrm{R}$ ('60); 8) R. E. Treybal: Ind. Eng. Chem, 52, 262 ('60); 53, 161 ('61); 9) T. J. Collopy, D. A. Stock; USAEC NLCO-801 ('60); 10) K. Naito: Bull. Chem. Soc. Japan 33, 363 ('60).

11) S. Mints, S. Libus: Radiokhimiya 2,643 ('60); 12) N. P. Wilburn: USAEC HW-66386 ('60); 13) N. M. Adamskii, S. M. Karpacheva, I. N. Mel'nikov, A. M. Rosen: Radiokhimiya 2, 13 ('60); 14) V. Moučka, J. Stary: Collection Czech. Chem. Commun. 26, 763 ('61); 15) W. E. Kedder: J. Inorg. Nucl. Chem, 16, 138 ('60); 16) A. S. Kertes, A. Beck, Y. Habousha: ibid., 21, 108 ('61); 17) E. Hesford, H. A. C. McKay: ibid., 13, 156 ('60); 18) W. E. Schuler: USAEC DP-513 ('60); 19) A. S. Kertes: J. Inorg. Nucl. Chem. 11, $\left.104\left({ }^{\prime} 60\right) ; 20\right)$ M. Taube: ibid., 15, $171\left({ }^{\prime} 60\right)$.

21) V. B. Shevchenko, A. S. Solovkin, I. V. Shilin, L. M. Kirillov, A.V.Rodionov, V.V.Balandina: Radiokhimiya 2, $281\left({ }^{\prime} 60\right)$; 22) H. Irving, D. C. Lewis: Proc. Chem. Soc. 1960, 222; 23) G. E. Boyd, Q. V. Larson: J. Phys. Chem. 64, 988 ('60); 24) K. B. Yatsimiǐskii: Izvest. Vysshikh Ucheb. Zaved. Khlm. i Khim. Tekhnol. 3, 823 ('60); 25) W. B. Brown, J. F. Steinbach, W. F. Wagner: J. Inorg. Nucl. Chem. 13, 119('60); 26) A. Vignes: J. Chim. phys. 57, 966, 980, 991, 999 ('60); 27) N. C. Deno, H. E. Berkheimer: J. Chem. Eng. Data 5, 1 ('61); 28) H. Watts; Australian J. Chem. 14, $15\left({ }^{\prime} 61\right)$; 29) K. Nukada, K. Naito, U. Maeda: Bull. Chem. Soc. Japan, 33, 894 ('60); 30) H. Saisho: ibid., 34, 1254 ('61).

31) E. Hesford, H. A. C. Mckay: J. Inorg. Nucl. Chem. 13, 165 ('60); 32) E. V. Komarov, M. F. Pushlenkov: Radiokhimiya 3, 567 ('61); 32) E. V. Komarov, M. F. Pushlenkov: ibid., 3, 575 ('61); 34) D. F. Peppard, J. R. Ferraro: J. Inorg. Nucl. Chem. 15, 365 ('60); 35) T. D. Smith: ibid., 15, $95\left({ }^{\prime} 60\right)$; 36) H. Irving, D. N. Edington: ibid., 15, 158 ('60); 37) H. Irving, D. N. Edington: ibid., 21, 169 ('61); 38) L. Newnan, P. Klotz: Phys. Chem, 65, 796 ('61); 39) V. M. Vdvenko, A. S. Krivokhatskii: Zhur. Neorg. Khim. 5, 494 ('60); 40) T. Shigematsu, M. Tabushi: Bull. Inst. Chem. Res., Kyoto Univ. 39, 34 ('61).

41) A. M. Roskanzer, B. M. Foreman: J. Inorg. Nucl. Chem. 16, 323 ('61); 42) H. Irving, R. S. Ramakrishna: Analyst, 85, 860 ('60); 43) 本鳥健次, 橋谷 博: 分化, 9, 151 ('60)；44）分析化学会編: “新分析化学講座” ('59) 共立 出版; 45) H. Bode, F. Neumann: Z. anal. Chem., 172,
1 ('60); 46) S. Shibata: Anal. Chim. Acta, 23, 367 ('60); 47) A. G. Kovaleva, L. M. Kul'berg: Uch. Zap. Sarator. Gsdarst. Univ., 71, 221 ('59); 48) F. L. Moore: USAEC NAS-NS-3101 ('60); 49) W. D. Arnold, D. J. Crouse: USAEC ORNL-3030 ('61); 50) 中川元吉：日化, 81, $444,446,747,750,1255,1258,1533,1536$ ('60); 82, 1042 ('61).

51) F. Ichikawa: Bull. Chem. Soc. Japan, 34, 183 ('61); 52) F. Ichikawa, S. Uruno: ibid., 33, 569 ('60); 53) T. Ishimori, H. M. Sammour, K. Kimura, H. Murakami, T. Izumi: J. Atom. Energy Soc. Japan, 3, 698 ('61); 54) M. L. Good, S. E. Bryan: J. Am. Chem. Soc. 82, 5636 ('60); 55) M. Ziegler, O. Glemser, A. vonBaekmann: Z. anal. Chem., 172, 105 ('60); 56) W. J. Maeck, G. L. Booman, M. E. Kussy, J. E. Rein: Anal. Chem., 33, 1775 ('61); 57) R. Neeb: Z. anal. Chem., 182, 10 ('61); 品川 睦明, 桂 幸招: 原子力誌, 2,147('60); 58) J. Yoshimura, K. Ueno: Memoir. Faculty of Sci., Kyushu Univ., Ser., C. Chem. 4, 63 ('61); 59) T. H. Siddall: J. Inorg, Nucl. Chem., 13, 151 ('60); 60) S. Nomura, R. Hara: Anal. Chim. Acta, 25, 212 ('61).

61) B. Weaver, D. E. Harner: J. Chem. Eng. Data 5, 260 ('60); 62) J. C. White, W. J. Ross: USAEC NASNS-3102 ('61); 63) T. Ishimori, K. Watanabe, E. Nakamura: Bull. Chem. Soc. Japan, 33, $636\left({ }^{\prime} 60\right)$; 64) T. Ishimori, K. Watanabe: ibid. 33, $1443\left({ }^{\prime} 60\right)$; 65) T. Ishimori, K. Watanabe, T. Fujino: J. Atom. Energy Soc. Japan 3, 19 ('61); 66) K. Kimura: Bull. Chem. Soc. Japan 33, 1038 ('60), 34, 63 ('61); 67) T. Sato: J. Inorg. Nucl. Chem. 16, 156 ('60); 68) 佐藤太一, 後藤 藤太郎: 工化, 63, 1586 ('60); 69) 石原健彦, 辻野毅, 山本 寛: 原子力学会誌, 2, 659 ('60); 70) G. Duykaerts, P. Dreze, A. Simon: J. Inorg. Nucl. Chem. 13, 332 ('60).

71) C. F. Baes, H. T. Baker: J. Phys. Chem. 64, 89 ('60); 72) J. R. Ferraro, J. W. Mason, D. F. Peppard: J. Inorg. Nucl. Chem. 22, 285 ('61); 73) C. G. Warren, J. F. Suttle: ibid. 12, $336\left({ }^{\prime} 60\right)$; 74) 後藤秀弘, 柿田八千代: 日化, 82, 1212 ('61)； 75） 後藤秀弘, 柿田八千代, 並木美智子; 同上, 82, 580 ('61); 76) 後藤秀弘, 柿田八千代, 並木美智子: 金属誌, 25, 178 ('61); 77) V. Vesely, H. Beranova, J. Maly: Coll. Czech. Chem. Commun. 25, 2622 ('60); 78) 多田格三, 大井 昇, 津下恭子: 日化, 81, $1554\left({ }^{\prime} 60\right)$; 79) P. R. Kuehn, O. H. Howard, C. W. Weber: Anal. Chem., 33, 740 ('61); 80) V. I. Kuznetsov, L. I. Bol'shakova: Zhur. Anal. Khim., 15, 523 ('60).

81) H. Saisho: Bull. Chem. Soc. Japan, 34, 859 ('61); 82) H. Gorican, D. Grdenic: Proc. Chem. Soc. 1960, 288; 83) T. Ishimori, E. Nakamura, H. Murakami: J. Atom. Energy Soc. Japan 3, 193, 590 ('61); 84) E. Nakamura: ibid., 3, 684 ('61); 85) J. M. White, P. Kelly, N. C. Li: J. Inorg. Nuc1. Chem., 16, 337 ('61); 86) G. Rudstam: Anal. Chem. 32, 1664 ('60); 87) T. W. Steel: Analyst 85, $\left.153\left({ }^{\prime} 60\right) ; 88\right)$ 木村健二郎, 石森富太郎, 内藤奎爾, 梅沢 弘一，渡辺賢寿: 原子力学会誌 $2,328\left({ }^{\prime} 60\right)$; 89) 木羽敏泰: 分 化, 9, 55 R ('60); 90) R. R. Brooks: Anal. Chim. Acta., 24, 456 ('61).

91）武内次夫, 深沢 力, 関谷恒人: 工化, 64, 93 ('61); 分化 10, 868 ('61); 92) 原重雄: 分化, 10, 629, 633 ('61); 93) K. L. Cheng: Anal. Chem. 33, 783 ('61); 94) 芦沢 峻: 分化, $10,350,354,443,449,555,558,683,688,817$ ('61); 95) T. Ishimori, H. M. Sammour: J. Atom. Energy Soc. Japan 3, 344, 410 ('61); 96) N. M. Isaac, P. R. Fields, D. M. Gruen: J. Inorg. Nucl. Chem. 21, 152 ('61); 97) G. K. Pel'sh, V. I. D'Yachkov: Uch. Zap. Leningrad. Gosud. Univ. 297, ('60); 98) J. Ruzicka, J. Starý: Talanta 8, 228 ('61); 99) W. J. Maeck, G. L. Booman M. C. Elliott, J. E. Rein: Anal. Chem. 32, 922 ('60); 100) T. Ishimori, T. Fujino: J. Atom. Energy Soc. Japan 3, 276 ('61). 
101) V. M. Dziomko: Dok. Akad. Nauk. SSSR 134, 1091 ('60)；102) 村田寿與：日化 81，1404,1408 ('60); 103) R. F. Rolf: Anal. Chem. 33, 125 ('61); 104) T. Kiba, S. Ohashi, T. Maeda: Bull. Chem. Soc. Japan 33, 818 ('60); 105) E. Jackwerth, H. Specker: Z. anal. Chem. 177, 327 ('60) 106) P. C. van Erkelens: Anal: Chim. Acta 25, 129 ('61); 107) A. M. Lefevre, J. F. Lefevre, A. Raggenbass: J. Inorg. Nucl. Chem. 12, 297 ('60); 108) 本島健次, 橋谷 博, 吉田秀世: 分化, 10, 79 ('61); 109) I. Adamiec: Rudy i Metale Niezalazne 5, 409 ('60); AA 8, 1385; 110) A. A. Nemodruck, V. V. Stasyuchenko: Zhur. Anal. Khim. 16, 407 ('61), AA 9, 1245.

111) H. Hartkamp: Z. anal. Chem., 176, 185 ('60); 112) R. E. Stoner, W. Dasler: Anal. Chem., 32, 1207 ('60); 113) J. O. Hibbits, W. F. Davis, M. R. Menke: Talanta, 4, 101 ('60); 114) 真島美智雄: 分化, 9, 272 ('60); 115) N. V. Koshkin: Trudy Komiss. Anal. Khim., Akad. Nauk, SSSR 11, 211 ('60), AA 9, 541; 116) I. H. Handley, J. A. Dean: Anal. Chem., 33, 1087 ('61); 117) 向山朝之, 一瀬典夫：分化, 10, $107\left({ }^{\prime} 61\right)$; 118) 武内次夫, 田中 保: 工化, 64, 305 ('61); 119) 宮本益夫：分化, 10, 321 ('61); 120) M. Ziegler, H. Sbrzesny, O. Glemser: Z. anal. Chem., 173, 411 ('60).

121) J. W. Murphy, H. E. Affsprung: Anal. Chem., 33, 1658 ('61); 122) M. Ziegler: Z. anal. Chem., 182, 166 ('61); 123) 平野四藏, 水池 敦, 山田光二: 分化, 9, 164 ('60); 124) C. J. Hardy, B. F. Greenfield, D. Scargill: J. Chem. Soc., 1961, 174; 125) J. R. Merrill, M. Honda, J. R. Arnold: Anal. Chem., 32, 1420 ('60); 126) 貴田勝造, 阿部 光伸, 西垣 進, 日下 武: 分化, 10, 663 ('61); 127) L. L. Galkina, A. L. Markman: Uzbek. Khim. Zhur., 1960, 53, AA 8, 3605; 128) R. F. Apple, J. C. White: Talanta, 8, 419 ('61); 129) S. J. Jankowski, H. Freiser: Anal., Chem., 33, 777 ('61); 130) K. T. Williams, J. R. Wilson: ibid. 33, 244 ('61).

131) W. L. Medlin: Anal. Chem., 32, 632 ('60); 132) 柿田八千代, 後藤秀弘: 東北大紀要, A 12, 334 ('60); 133) D. W. Margerum, F. Santacana: Anal. Chem., 32, 1157 ('60); 134) J. Růźička, J. Starý: Talanta, 8, 296 ('61); 135) 前川静弥, 米山善夫: 分化, 10,736 ('61); 136) P. V. Marchenko: Zavod. Lab., 26, 532 ('60), AA 8, 49; 137) Y. I. Usatenko, F. M. Tulyupa: ibid., 26, 783 ('60), AA 8, 954; 138) S. S. Yamamura: Anal. Chem., 32, 1896 ('60); 139) 上原 寞, 浜田修一: 工化, 63, 1580 ('60); 140) J. Růžička, J. Stary: Talanta, 8, 535 ('61).

141）濑野英夫，柿田八千代：日化，82，452 ('61)；142） E. A. Hakkila, G. R. Waterbury: Anal. Chem., 32, 1340 ('60); 143) L. Pasztor, J. D. Bode: ibid., 32, 1530 ('60); Anal. Chim, Acta, 24, 467 ('61); 144) I. A. Blyum, T. K. Dushina, T. V. Semenova, I. Ya. Scherba: Zavod. Lab., 27, 644 ('61), AA 9, 576; 145) A. K. Kabko, P. V. Marchenko: ibid. 26, 1202 ('60), AA 8, 2419; 146) F. A. Pohl, K. Kokes, W. Bonsels: Z. anal. Chem., 174, 6 ('60); 147) 本島健次, 井沢君江: 原子力学会誌, 2, 253 ('60); 148）宮本养夫：分化，10，98 ('61)；149）石橋雅義, 重松恒信, 西川泰治: 日化, 81, $259\left({ }^{\prime} 60\right)$; 150) L. M. Skrebkova: Zhur. Anal. Khim., 16, 422, ('61), AA 9, 989, cf. AA 8, 1823.

151）石祜雅義, 重松恒信, 西川泰治, 平井敬三：日化, 82, 1141 ('61); 152) Yu. A. Bankovsky, Ya. A. Tsirule, A. F. Ievinš: Zhur. Anal. Khim., 16, 562 ('61); 153) S. Shibata: Anal. Chim. Acta, 23, 434 ('60); 154) M. Ziegler: Z. anal. Chem., 180, 348 ('61); 155) 宮本益夫: 分化, 10, 102 ('61); 156) W. B. Stavinoha, J. B. Nash: Anal. Chem., 32, 1695 ('60); 157) I. A. Blyum, I. T. Solov'yan, G. N. Shebalkova: Zavod. Lab., 27, 950 ('61), AA 9, 1021; 158) T. C. Rains, H. P. House, Oscar Menis: Anal. Chim. Acta, 22, 315 ('60); 159) D.
Dyrssen, D. H. Lien: Acta Chem. Scand., 14, 1100 ('60); 160) R. J. Velten, A. S. Goldin: Anal. Chem., 33, 128 ('61).

161) J. J. McCown, R. P. Larsen: Anal. Chem., 32, 597 ('60); 162) S. M. Khopkar, A. K. De: ibid., 32, 478 ('60); 163) R. D. Britt, Jr.: ibid., 33, 602 ('61); 164) J. P. Young, J. C. White, R. G. Ball: ibid., 32, 928 ('60); 165）吉田博之, 高橋正婎: 分化, 10, 954 ('61); 166) H.N. Wilson, J. M. Skinner: Rec. trav. chim., 79, 574 ('60); 167）石井大道, 武内次夫：分化, 10, 1394 ('61); 168) 宮本 益夫: 同上, 10, 433 ('61); 169) A. I. Zelyanskaya, N. V. Stashkova: Zhur. Anal. Khim, 16, 430 ('61), AA 9, 1000; 170) A. Hillebrant, J. Hoste: Anal. Chim. Acta,: 18, 569 ('58).

171) D. D. Gilbert, E. B. Sandell: Mikrochem. J., 4, 491 ('60); 172) W. Oelschläger: Z. anal. Chem.,: 174, 241 ('60): 173) W. J. Ross, J. C. White: Anal. Chem., 33, 424 ('61); 174) N. V. Lebedeva, V. A. Nazarenko: Trudy Kommis. Anal. Khim. Akad. Nauk. SSSR., 1960, 63; 175) J. F. W. Tertoolen, D. A. Detmer, C. Buijze; Z. anal. Chem., 167, 401 ('59); 176) D. F. Wood; H. A. Nicholls: Analyst, 85, $139\left({ }^{\prime} 60\right)$; 177) M. Ziegler: Z. anal. Chem., 180, 351 ('61); 178) 斎藤 謙, 武内次夫：分 化, 10, 152 ('61); 179) J. O. Hibbits, W. F. Davis, M. R. Menke: USAEC APEX-523 ('59); 180) A. S. Golüin, R. J. Velten; Anal. Chem., 33, 149 ('61).

181) C. J. Hardy, D. Scargill: J. Jnorg. Nucl. Chem., 17, 337 ('61); 182) H. Umezawa, R. Hara: Anal. Chim. Acta, 23, 267 ('60); 183) 星野芳夫: 日化, 81, 1574 ('60); 184) W. C. Pietrich: USAEC Y-1329 ('61); 185) J. H. Stewart, Jr.: Anal. Chem., 32, 1090 ('60); 186) 八木一郎, 睠又茂: 工化, 64, 1926 ('60); 187) V. M. Peshkova, A. P. Zozulya: Zhur. Anal. Khim., 14, 41 ('59); 188) H. P. Holcomb, J. H. Yoe: Microchem J., 4, 463 ('60); 189) G. Picasso: Met. ital., 15, 358 ('60); 190) 石井大道, 武内 次夫: 分化, 10, 1391 ('61).

191) K. Sugawara, S. Kanamori: Bull. Chem. Soc. Japan, 34, 258 ('61); 192) 並木 博: 分化, 10,945 ('61); 193）柳生正武: 同上, 10, 235 ('61); 194) H. C. Beard, L. A. Lyerly: Anal. Chem., 33, 1781 ('61); 195) V. I. Levin, M. M. Golutvina: Metody Polycheniya i Izmeren, Radioaktiv. Preparatov. Sbornik Statei: 1960, 63; 196) K. Saito, S. Ikeda, M. Saito: Bull. Chem. Soc. Japan, 今3, 884 ('60); 197) 鈴木信男: 日化, 81, 437 ('60); 198) R. W. Lowe, S. H. Prestwod, R. R. Richard, F. I. Wyatt: Anal. Chem., 33, 874 ('61)；199）神原富尚, 大塕 裕, 塩沢 カョ子: Radioisotopes, 10, $\left.217\left({ }^{\prime} 61\right) ; 200\right)$ S. Meyer, O. G. Koch: Z. anal. Chem., 179, 175 ('61).

201) H. A. Mottola, E. B. Sandell: Anal. Chim. Acta, 24, 301 ('61); 202) N. Matano, A. Kawase: Trans. Nat. Res. Insh. Met. Japan, 1, 69 ('59); 203) 宮本养夫: 分化, 10, 317 ('61); 前川清弥, 米山善夫, 藤森英一. 同上, 10, 345 ('61); 204) U. Priydarshini, S. G. Tandon: Analyrt, 86, 544 ('61); 205) S. G. Tandon, S. C. Bhattacharyya: Anal. Chem., 33, 1267 ('61); 206) H. Amano: Sci. Repts. Research Inst., Tohoku Univ. Ser., A 12, 24 ('60); 207) L. A. Balchin, D. I. Williams: Analyst, 85, 503 ('60)；208）菅野草治，阿部重喜، 岡 好良: 日化, 82,1362 ('61); 209) I. P. Alimarin, O. M. Petrukin, Y. H. Chieh: Doklady Akad. Nauk. SSSR, 136, 1073 ('61); 210) K. Motojima, H. Hashitani: Anal. Chem., 33, 48 ('61).

211) A. T. Pilipenko, V. A. Obolonchik: Vopr. Poroshk. Metallurg. i Prochnosti Matr., Akad. Nauk Ukr. SSR 8, 131 ('60): AA 8, 4597; 212) 西村山治, 森山徐一郎, 久鼠亥三 雄: 金属誌, 25, 27, 112 ('61) など; 213) E. K. Hyde, E. K. Katzin, M. J. Wolf: USPatent 2894827 ('59); 214) J. J. McCarmack, F. H. Cripps, W. A. Wiblin: Anal. Chim. Acta, 22, 408 ('60); 215) 岩䗁岩次, 岸岡 明, 吉田萃人; 分 
化, 10，479 ('61)；216) 湯浅辉：同上, 10, 965 ('61)；217) H. Ariyoshi, M. Kiniwa, K. Toei: Talanta, 5, 112 ('60); 218）浜口 博，太田直一，小沼直樹，川崎克彦：日化，81，920 ('60); 219) 阪上正信: 同上, 81, 242 ('60); 220) S. Hikime: Bull. Chem. Soc. Japan, 33, 761 ('60).

221) V. N. Pavlova, N. G. Vasiléva, S. E. Kashlinskaya: Zavod. Lab., 27, 965 ('61), AA 9, 1033; 222) K. L. Cheng: Talanta, 8, 301 ('61); 223) N. Matsuura, A. Ouchi, M. Kojima: Bull. Chem. Soc. Japan. 34, 411 ('61); 224) F. L. Moore: Anal. Chem., 32, $1048\left({ }^{\prime} 60\right)$; 225) S. K. Majumdar, A. K. De: ibid, 32, 1337 ('60); 226) K. Motojima, H. Hashitani: ibid., 33, $239\left({ }^{\prime} 61\right)$; 227) S. A. Katz, W. M. McNabb, J. F. Hazel: Anal. Chim Acta, 25, 193 ('61); 228) V. G. Pogodaeva, K. P. Stolyarav: Uch. Zap. Leningrad. Gos. Univ., (297), 170 ('60); 229) J. O. Hibbits, W. F. Davis, M. R. Menke, S. Kallman; Talanta, 4, 104 ('60); 230) G. Almássy, M. Vigvári: Acta. Chim. Acad. Sci. Hung., 20, 243 ('59).

231) A. I. Buser, Chzhan Fan: Zhur. Anal. Khim., 16, 578 ('61); 232) 吉森孝良, 武内次夫: 分化, 9, 689 ('60); 233) W. J. Maeck, M. E. Kussy, J. E. Rein: Anal. Chem., 33, 237 ('61); 234) 小松毒美雄; 日化, 82, 265 ('61); 235) A. I. Buser, V. M. Byr'ko, I. I. Grandbery: Vestn. Moskov. Univ., Ser. Khim. 1960, II, 76; 236) V. Pfeifer: Mikrochim. Acta, 1960, 518; 237) V. Pfeifer, F. Hecht: Z. anal. Chem., 177, 175 ('60); 238) P. W. West, A. S. Lovica: Anal. Chim. Acta, 25, 28 ('61); 239) 友成明久: 日化, 82, 864 ('61); 240) Van Yun-Yui, V. A. Khalkin: Radiokhimiya, 3, 662 ('61).

241) J. M. Matuszek, Jr., T. T. Sugihara: Anal. Chem., 33, 35 ('61); 242) S. J. Rimshaw, G. F. Malling: ibid., 33, 751 ('61); 243) F. J. Miller, P. F. Thomason: ibid., 404 ('61); 244) T. Ishimori, E. Nakamura, J. Akatsu: J. Atom. Energy Soc. Japan 3, 767 ('61)； 245）石橋雅義, 藤永太一郎, 小山陸夫: 日化, 82, $\left.185\left({ }^{\prime} 61\right) ; 246\right)$ A. T. Pilipenko, V. A. Obolonchik: Ukrain. Khim. Zhur. 28, 99 ('60); 247) J. Toul, A. Okac: Spisy Prirodovedecké fak. Univ. Brné. 417, 407 ('60); 248) K. Beyermann: Z. anal. Chem. 183, 91 ('61); 249) 重松恒信, 田伏正:之: 日化 81, 622 ('60); 250) V. P. Zhivopistev, A. A. Minin: Zavod. Lab., 26, 1346 ('60).

251) R. J. Dutta: J. Indian Chem. Soc., 37, 167 ('60); 252）川畑正夫, 望月平一, 三崎刚：分化, 10, 15 ('61); 253) A. B. Blank, A. M. Bulgakova: Zhur. Anal. Khim., 15, 605 ('60); 254) K. H. Lieser, H. Schroeber: $Z$. anal. Chem., 174, 174 ('60); 255) S. M. Khopkar, A. K. De: Anal. Chim. Acta, 22, 223 ('60); 256) 吉森孝良, 富田 与志郎, 武内次夫: 分化, 10, 156 ('61); 257) G. Weidmann: Can. J. Chem., 38, 459 ('60); 258) S. K. Majumdar, A. K. De; Talanta 7, 1 ('60); 259) J. O. Hibbits, W. F. Davis, M. R. Menke: ibid., 4, 61 ('60); 260) 川烟正夫, 望月平一, 三崎 剛: 分化, 9, 1023 ('60).

261) Y. L. Lel'chuk, L. L. Skripova, P. V. Kristalev:
Izvest. Sibirsk. Otdel, Akad. Nauk. SSSR 1960, 63, A A 9, 706; 262) K. P. Stolyarov: Zhur. Anal. Khim., 16, 452 ('61), A A 9, 1062; 263) P. C. van Erkelens: Anal. Chim. Acta, 24, 526 ('61); 264) L. M. Gindin, I. F. Kopp, A. M. Rosen, P. I. Bobikov, E. F. Kouba, N. A. TerOganesov: Zhur. Neorg. Khim., 5, 149 ('60); 265) J. O. Hibbits, A. F. Rosenberg, R. T. Williams: Talanta, 5, 250 ('60); 266) V. T. Athavale, S. V. Gulavanne, M. M. Tillu: Anal. Chim. Acta, 23, 487 ('60); 267) 真島 美智雄：分化， S, 269 ('60); 268) 道野鹤松, 中川元吉, 和田 弘子: 日化, 32, 590 ('61); 269) A. B. Blank, A. M. Bulgakova, N. T. Sizonenko: Zhur. Anal. Khim., 16, 715 ('61)；270) 本島健次, 橋谷 博, 勝山和夫: 原子力学会誌, 3 $89(' 61)$.

271) W. L. Belew, G. R. Wilson, L. T. Corbin: Anal. Chem., 33, 886 ('61); 272) J. Brandštetr, J. Vreštál: Collection Czech. Chem. Commun., 26, 392 ('61); 273) T. Hara, E. B. Sandell: Anal. Chim. Acta. 23, 65 ('61); 274) J. H. W. Forythe, R. J. Magee, C. L. Wilson: Talanta, 3, 324, 330 ('60); 275) 道野鹤松, 中川元吉, 林 誠: 日化, 81, 1703 ('60); 276) V. I. Shlenskaya, S. S. Sokolov: Jrudy Komissii Anal. Khim., Akad. Nauk SSSR 11, 328 ('60); 277) 小松寿美雄, 上山精二: 日化, 81, 1096 ('60); 278) S. E. Kreimer, L. P. Butylkin, A. V. Stogova: Zhur. Anal. Khim., 15, 467 ('60); 279) 下島 光: 日化, 82, 1186 ('61); 280) G. Goldstein: USAEC CF$59-643 ;-7-16$ ('59).

281) R. B. Wilson, W. D. Jacobs: Anal. Chem., 33, 1650 ('61); 282) S. Shibata: Anal: Chim. Acta, 22, 479 ('60); 283) C. E. Meloan, P. Holkeboer, W. W. Brandt: Anal. Chem., 32, 791 ('60); 284) V. I. Kutznetsov, S. B. Savvin: Radiokhimiya, 2, $682\left({ }^{\prime} 60\right)$; 285) V. I. Kutznetsov, T. N. Kukisheva: Zavod. Lab., 26, 1344 ('60); 286) 重松恒信, 田伏正之: 日化, 81, 265 ('60); 287) P. A. Vozzella, A. S. Powell, R. H. Gale, J. E. Kelly: Anal. Chem., 32, 1430 ('60); 288) Yu. V. Morachevskii., I. A. Tserkovnitskaya, M. F. Grigv'ev: Uch. Zap. Leningrad. Gos. Univ(297), 119 ('60). AA 9, 111; 289) K. Motojima, K. Yoshida, K. Izawa: Anal. Chem., 32, 1083 ('60); 290) W. B. Smith, K. Drewry: Analyst, 86, 178 ('61).

291) B. N. Laskorin, V. F. Smirnov: Zhur. Priklad. Khim., 33, $2172\left({ }^{\prime} 60\right)$; 292) T. Ishimori, E. Nakamuraia: Bull. Chem. Soc. Japan, 32, 713 ('59); 293) R. F. Buchanan, J. P. Hughes, J. J. Hines, C. A. A. Bloomquist: Talanta, 6, 173 ('60); 294) W. J. Meck, M. E. Kussy, G. L. Booman: Anal. Chem., 33, 998, 1874 ('60); 295) H. Umezawa: J. Atom. Energ. Soc. Japan, 2, 478 ('60); 296) T. Ishimori, K. Watanabe, T. Fujino: ibid., 3, 507 ('61); 297) F. L. Moore: Anal. Chem., 33, 748 ('61); 298) N. M. Isaac, J. W. Wilkins, P. R. Fields: J. Inorg. Nucl. Chem., 15, 151 ('60); 